\title{
1976 IRRUPTION \\ OF CLARK'S NUTCRACKER \\ IN CYPRESS HILLS, ALBERTA
}

ROBERT M. FISHER, 3719 Centre A Street, N.E., Calgary, Alberta, T2E 3 A5.

On 18 August 1976 at 1600 hrs., park naturalists Doug Leriger and the author identified a Clark's Nutcracker in Cypress Hills Provincial Park, Alberta. The bird was sitting on top of a $15-\mathrm{m}$ lodgepole pine Pinus contorta var. latifolia near Horseshoe Canyon (Lat. $41^{\circ} 38^{\prime}$ Long. $110^{\circ} 18^{\prime}$ ) at an elevation of $1430 \mathrm{~m}$. Groups of 3-6 birds were observed almost daily in the area for the next week. The nutcrackers fed exclusively on grasshoppers during the 2 hours we observed them even though pine cones were available.

On 25 August 1976, at 1535 hrs., Doug Leriger observed a flock of 30 nutcrackers flying in the same area as the previous sighting. The birds flew just above the tree tops and disappeared over a hill, never to be seen as a flock again. Several photographs were taken of individual birds. The observations have been placed in the Alberta Ornithological Committee Active File as a substantiated record (Dr. J. Salt pers. comm. 1978).

Clark's Nutcracker is a permanent resident of the subalpine forests of the Rocky Mountains. ${ }^{3}$ Every autumn and winter individuals descend to the coniferous and mixed wood forests of the Canadian Zone of Alberta and, in autumn and winter of certain years, single individuals or flocks disperse to lower elevations many kilometers from the mountain forests.2 Although single birds have been recorded from Ravenscrag in the Saskatchewan Cypress Hills, the above observation is the first published record for Cypress Hills, Alberta. 4

The significant aspect of the observation is the unusual number of individuals involved. A search through the literature indicated the vast majority of extralimital occurrences of Clark's Nutcracker in Canada are of single individuals or groups of 2-5. The large number of individuals in Cypress Hills, Alberta, should be considered an irruption. The mysterious aspect of the observation is where did the birds go after the last sighting on 4 September? No extralimital occurrences were reported in Saskatchewan or Montana. However, flocks of 30 and 20 nutcrackers were recorded in the Porcupine Hills, $300 \mathrm{~km}$ west of Cypress Hills, on 25 September $1976 .{ }^{1}$

If anyone has unpublished observations of Clark's Nutcracker outside its normal range, the author would be glad to receive them.

1BUTOT, R. 1977. Natural history observations: birds. Calgary Field Naturalist 8:181-188.

2SADLER, T. S. and M. T. MYRES. 1976. Alberta Birds, 1961-1970, with particular reference to migration. Prov. Mus. Alta., Nat. Hist. Sect. Occasional Paper No. 1. Alberta Culture. Historical Research Division. 292 pp.

3SALT, W. R. and J. R. SALT. 1976. The birds of Alberta. Hurtig Publ., Edmonton. $495 \mathrm{pp}$.

${ }^{4}$ SEALY, S. G. 1971. The occurrences of some western birds in Saskatchewan. Blue Jay 29:184-196. 